\title{
Designed whole-cell-catalysis-assisted synthesis of 9,11-secosterols
}

\author{
Marek Kõllo ${ }^{1}$, Marje Kasari², Villu Kasari², Tõnis Pehk ${ }^{3}$, Ivar Järving ${ }^{1}$, Margus Lopp ${ }^{1}$, \\ Arvi Jõers ${ }^{2}$ and Tõnis Kanger ${ }^{* 1}$
}

\section{Full Research Paper}

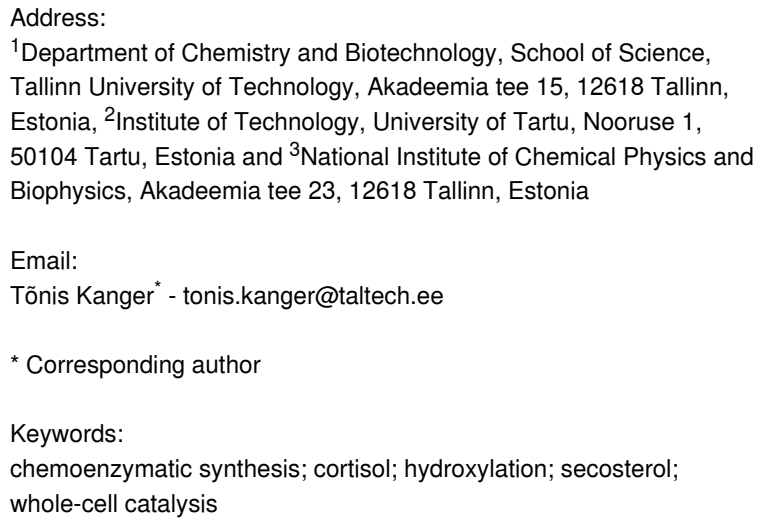

${ }^{1}$ Department of Chemistry and Biotechnology, School of Science, Tallinn University of Technology, Akadeemia tee 15, 12618 Tallinn, Estonia, ${ }^{2}$ Institute of Technology, University of Tartu, Nooruse 1, 50104 Tartu, Estonia and ${ }^{3}$ National Institute of Chemical Physics and Biophysics, Akadeemia tee 23, 12618 Tallinn, Estonia

Email:

Tõnis Kanger* - tonis.kanger@taltech.ee

* Corresponding author

Keywords:

chemoenzymatic synthesis; cortisol; hydroxylation; secosterol; whole-cell catalysis

\author{
Beilstein J. Org. Chem. 2021, 17, 581-588. \\ https://doi.org/10.3762/bjoc.17.52 \\ Received: 07 January 2021 \\ Accepted: 17 February 2021 \\ Published: 01 March 2021 \\ This article is part of the thematic issue "Green chemistry II". \\ Associate Editor: L. Vaccaro \\ (C) 2021 Kõllo et al.; licensee Beilstein-Institut. \\ License and terms: see end of document.
}

\section{Abstract}

A method for the synthesis of 9,11-secosteroids starting from the natural corticosteroid cortisol is described. There are two key steps in this approach, combining chemistry and synthetic biology. Stereo- and regioselective hydroxylation at C9 (steroid numbering) is carried out using whole-cell biocatalysis, followed by the chemical cleavage of the $\mathrm{C}-\mathrm{C}$ bond of the vicinal diol. The two-step method features mild reaction conditions and completely excludes the use of toxic oxidants.

\section{Introduction}

Developments in the chemistry of steroids have stimulated extensive research interest in the exploration of new synthetic methods since the 1960s. Advances in synthetic biology and the increasing importance of methods of sustainable chemistry have brought chemoenzymatic approaches for obtaining natural products, or derivatives thereof, with complex structure into focus [1]. Various enzymatic or semisynthetic methods have also been exploited in the synthesis of steroids [2-4]. A more challenging synthesis of secosteroids with unique broken tetracyclic carbon skeletons and abeo-steroids with migrated bonds has received attention only recently $[5,6]$. As the bond cleavage may occur at the 5,6-, 9,11-, 9,10-, 8,9-, 8,14- or 13,17-positions (Figure 1A), the selection of synthetic methods for secosteroids is wide. However, usually these are multistep sequences exploiting toxic oxidants.

Marine invertebrates are a rich source of oxidated and highly functionalized steroidal metabolites, including secosteroids. Since the first isolation of 9,11-secosterol from Pseudopterogorgia americana in 1972 (Figure 1B) [7], several others from 


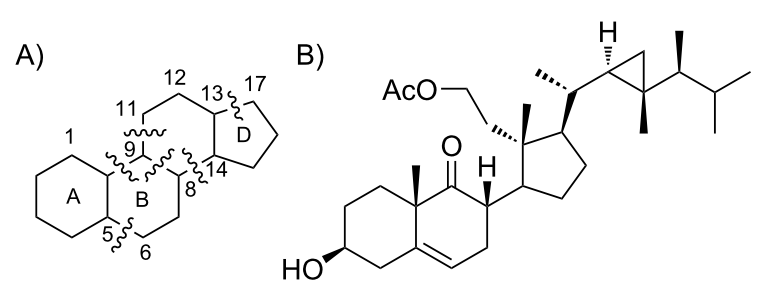

Figure 1: A) Tetracyclic core of steroids and possible sites of bond cleavages for secosteroids. B)The first 9,11-secosteroid isolated in 1972 [7].

the family have been reported [8-14]. The 9,11-secosterols exhibit diverse biological activities, including antihistaminic, antiproliferative, anti-inflammatory, cytotoxic and protein kinase $\mathrm{C}$ (PKC) inhibition activities [8-10,15]. Biochemical characterization of 9,11-secosterols has so far mainly relied on the identification and purification of natural products from marine invertebrates. The intriguing profile of biological properties has prompted synthetic studies of this class of secosterols. The majority of synthetic schemes starts with natural steroids, taking advantage of the appropriate stereochemistry of existing stereogenic centres [16-20]. However, the synthesis of target compounds is a multistep procedure, often including several protections and deprotections of functional groups.

Our approach to 9,11-secosterols is depicted in the retrosynthetic analysis in Scheme 1. There are two key steps in obtaining the skeleton of the secosterol. The first is (di)hydroxylation at $\mathrm{C} 9$ (C11), and the second is C9-C11-bond cleavage, which can be carried out by a well-developed chemical oxidation of 1,2-diols. Starting with a compound already possessing a hydroxy group at the position C11, only hydroxylation at C9 is needed. Commercially available corticosteroid cortisol already possesses a hydroxy group at the position $\mathrm{C} 11$, and therefore only hydroxylation at C9 is needed, making cortisol (1) an ideal starting compound for this synthesis.

Chemical oxidation methods for the synthesis of steroids often require stoichiometric amounts of toxic reagents, and the selectivity of the oxidation is still an unsolved problem [21].
Typically, toxic oxidants, such as $\mathrm{OsO}_{4}, \mathrm{SeO}_{2}$ and $\mathrm{Pb}(\mathrm{OAc})_{4}$ are used in this total synthesis sequence. Inspired by several enzymatic oxidations [22-25], we envisioned to carry out oxidation at $\mathrm{C} 9$ in an environmentally benign way using an oxidation by a whole-cell biocatalysis method.

The first, and so far the only chemoenzymatic synthesis of 9,11secosterols using cellular lysate of the marine gorgonian Pseudopterogorgia americana was published by Keliman et al. in 1996 [26]. They carried out quite effective transformations of a variety of sterols to 9,11-secosteroid derivatives in high yields. However, it is unclear which enzymes were responsible for each oxidation step through the whole secosteroid synthesis pathway. Also, the use of cellular lysate from a nonlaboratory organism prevents any widespread adoption of this method.

Herein, we present a new combined route towards 9,11-secosterols via stereo- and regiospecific enzymatic hydroxylation at C9, followed by the chemical oxidative cleavage of the 9,11$\mathrm{C}-\mathrm{C}$ bond. For the hydroxylation, we used a biocatalyst derived from an Escherichia coli laboratory strain BL21 (DE3) overexpressing the kshA5 and $k s h$ genes from Rhodococcus. rhodochrous. Cortisol (1) was chosen as a model steroidal structure.

\section{Results and Discussion Synthesis of starting compounds for enzymatic hydroxylation}

In order to estimate the possible diversity of the substrates as starting materials for the biocatalytic transformation, cortisol (1) was converted to a hydroxylated steroid derivative 2 by reduction of the $\mathrm{C} 20$ carbonyl group with $\mathrm{NaBH}_{4}$ and subsequent oxidative cleavage of the intermediate 17,20,21-trihydroxy side chain with $\mathrm{NaIO}_{4}$ in $99 \%$ total yield (Scheme 2) [27].

The $\mathrm{C} 11$ hydroxy group was protected with acetic anhydride in the presence of a base, resulting in C11-protected product 3 in 93\% yield. Performing the same reaction under microwave irradiation, a mixture of monoacylated and diacylated products $\mathbf{3}$ and 4 in 52\% and 33\% yield, respectively, was isolated [28].<smiles>[R]C1CC[C@H]([C@H]2CCC3=CC(=O)CC[C@]3(C)C2=O)[C@@H]1CC=O</smiles>

9,11 -secosterol

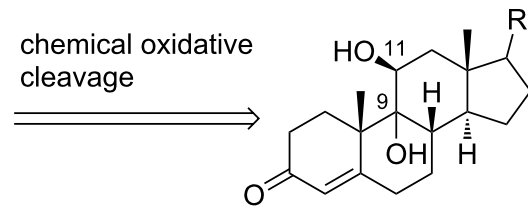

diol

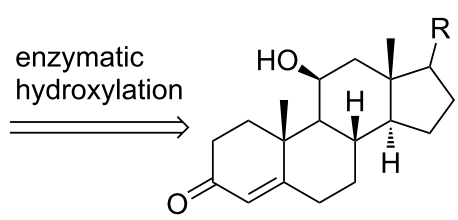

Scheme 1: Retrosynthetic analysis of 9,11-secosterols. 


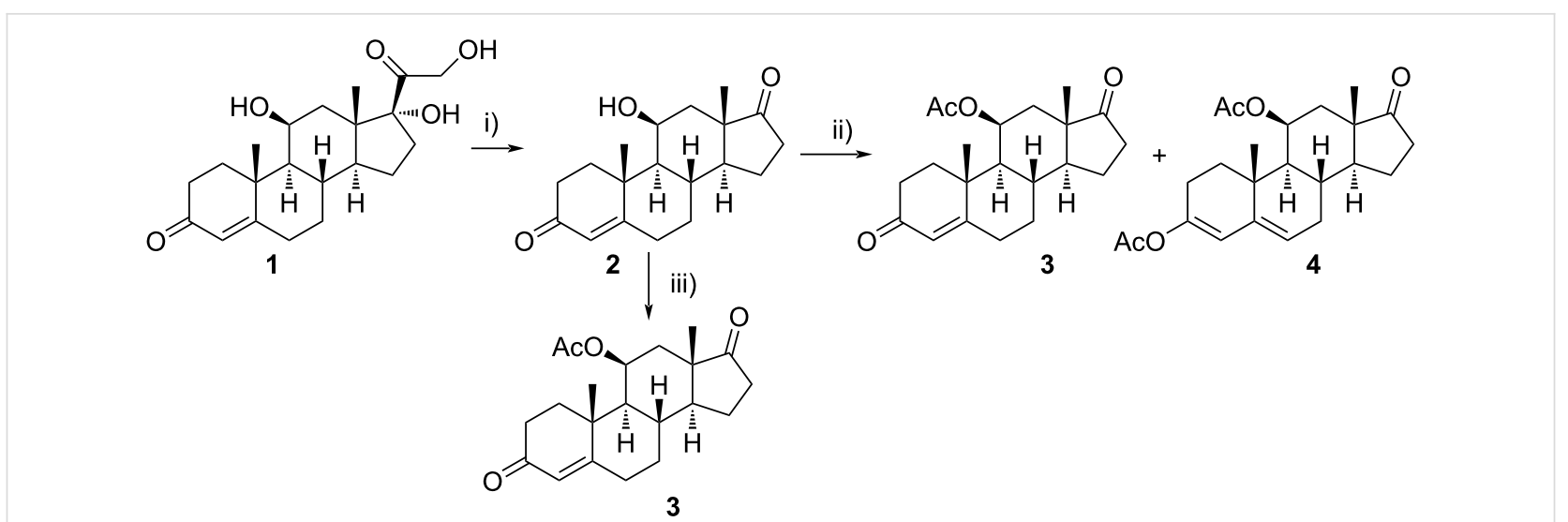

Scheme 2: Synthesis of starting materials. Reagents and conditions: i) $\mathrm{NaBH}_{4}, \mathrm{EtOH} / \mathrm{CH}_{2} \mathrm{Cl}_{2} 1: 1,2 \mathrm{~h}$, rt, then acetone, $\mathrm{H}_{2} \mathrm{O}, \mathrm{NalO}$, overnight, rt, $99 \%$; ii) $\mathrm{Ac}_{2} \mathrm{O}, p-\mathrm{TsOH}(1 \mathrm{~mol} \%)$, MW (800 W), 6 min, $52 \%$ for 3 and $33 \%$ for 4 ; iii) $\mathrm{Ac}_{2} \mathrm{O}, \mathrm{DMAP}, \mathrm{Et}_{3} \mathrm{~N}, \mathrm{CH}_{2} \mathrm{Cl}_{2}, \mathrm{overnight}$, rt, $93 \%$.

\section{Enzymatic hydroxylation}

3-Ketosteroid $9 \alpha$-hydroxylase (KSH) from $R$. rhodochrous has been shown to oxidize $C 9$ in several steroids [29]. This enzyme consists of two polypeptides: KshA (terminal oxygenase) and $\mathrm{KshB}$ (ferredoxin reductase). When expressed together in E. coli, active $\mathrm{KSH}$ is formed, and several steroids can be oxidized in the C9 position [29,30]. Out of five KshA homologues found in $R$. rhodochrous, only KshA5 is able to utilize C11hydroxylated cortisone, 11 $\beta$-hydrocortisone, as a substrate [30].

For the construction of the biocatalyst, $k s h A 5$ and $k s h B$ genes from $R$. rhodochrous were codon-optimized for enhanced expression in E. coli and cloned into a pET21a protein expression plasmid. To obtain an active biocatalyst, the plasmid was transformed into an E. coli BL21 (DE3) strain, and protein expression was induced by the addition of IPTG. Substrates of biocatalysis were added together with the IPTG inducer. The whole-cell biocatalysis was performed overnight at $30{ }^{\circ} \mathrm{C}$ in a rich medium with continuous shaking. Cell pellet and culture supernatant were collected the next morning for further analysis. A typical reaction contained approximately $40 \mathrm{mg}$ of substrate in $200 \mathrm{~mL}$ culture medium, depending on the solubility and availability of substrates. This reaction can be scaled up by increasing the culture volume; the substrate concentration cannot be increased due to the low solubility of corticosteroids in aqueous solution. The expression of KshA5 and KshB was verified from the cell lysate by polyacrylamide gel electrophoresis and western blotting (see Supporting Information File 1, Figure S1). The product distribution between the cellular pellet and supernatant was approximately 1:10 (estimated by HRMS analysis). The steroid compounds were extracted from the supernatant and purified by column chromatography on silica gel as the stationary phase. The outcome of the enzymatic hydroxylation in position $\mathrm{C} 9$ using $\mathrm{KSH}$-based biocatalysis is given in Table 1.
With substrates $\mathbf{1}$ and 2, enzymatic hydroxylation proceeded efficiently and selectively at C9, affording trans-9,11-dihydroxysteroids 5 and $\mathbf{6}$, respectively. For compound 5, 67\% of the starting compound was isolated. In Table 1, entry 2 , several unidentified products were also formed. With 11-acetoxy steroid 3, the C9-hydroxylated product $\mathbf{7}$ was isolated together with unreacted starting steroid 2. Conjugated enol ester $\mathbf{4}$ did not react, and only the starting compound was detected in the reaction mixture. This indicates that the $\mathrm{C} 3$ carbonyl group in substrates is essential for enzymatic hydroxylation, as has been shown before [29]. A positive control experiment with the same batch of KSH-expressing E. coli cells using cortisol (1) as a substrate yielded C9-hydroxylated product 5. From the results, we can also conclude that a protected $\mathrm{C} 11$ hydroxy group decreases the effectiveness of enzymatic transformation. Also, the substituent at $\mathrm{C} 17$ does not affect the KSH performance: steroids with $\mathrm{C} 17$ keto functionality (i.e., $\mathbf{2}$ and $\mathbf{3}$ ) or cholesterol-like side chains at C20 (i.e., 1) were all transformed efficiently to the corresponding 9,11-dihydroxylated products. ${ }^{1} \mathrm{H}$ and ${ }^{13} \mathrm{C}$ 1D and 2D (COSY, HSQ and HMBC) NMR spectra from samples $\mathbf{5}$ and $\mathbf{6}$ were analyzed, as were the spectra of the starting compounds $\mathbf{1}$ and $\mathbf{2}$. The assignment of all ${ }^{1} \mathrm{H}$ and ${ }^{13} \mathrm{C}$ signals confirmed the preservation of the configuration of the ring system and substituents in these whole-cell transformations, as well as the $\mathrm{OH}$ group connections to $\mathrm{C} 9$.

\section{Chemical oxidation of 9,11-dihydroxysteroids}

In the final step, the obtained trans-diols $\mathbf{5}$ and $\mathbf{6}$ were subjected to the chemical oxidation of the 9,11 carbon bond. Lead tetraacetate is a classic oxidant for the cleavage of vicinal diols. However, there are serious drawbacks when using $\mathrm{Pb}(\mathrm{OAc})_{4}$. In addition to its toxicity, the oxidation rate affording trans-diols was very slow in comparison to that for cis-diols. Using an even longer reaction time and stoichiometric amount of the reagent, diol 5 was not oxidized to the corresponding dicarbonyl com- 


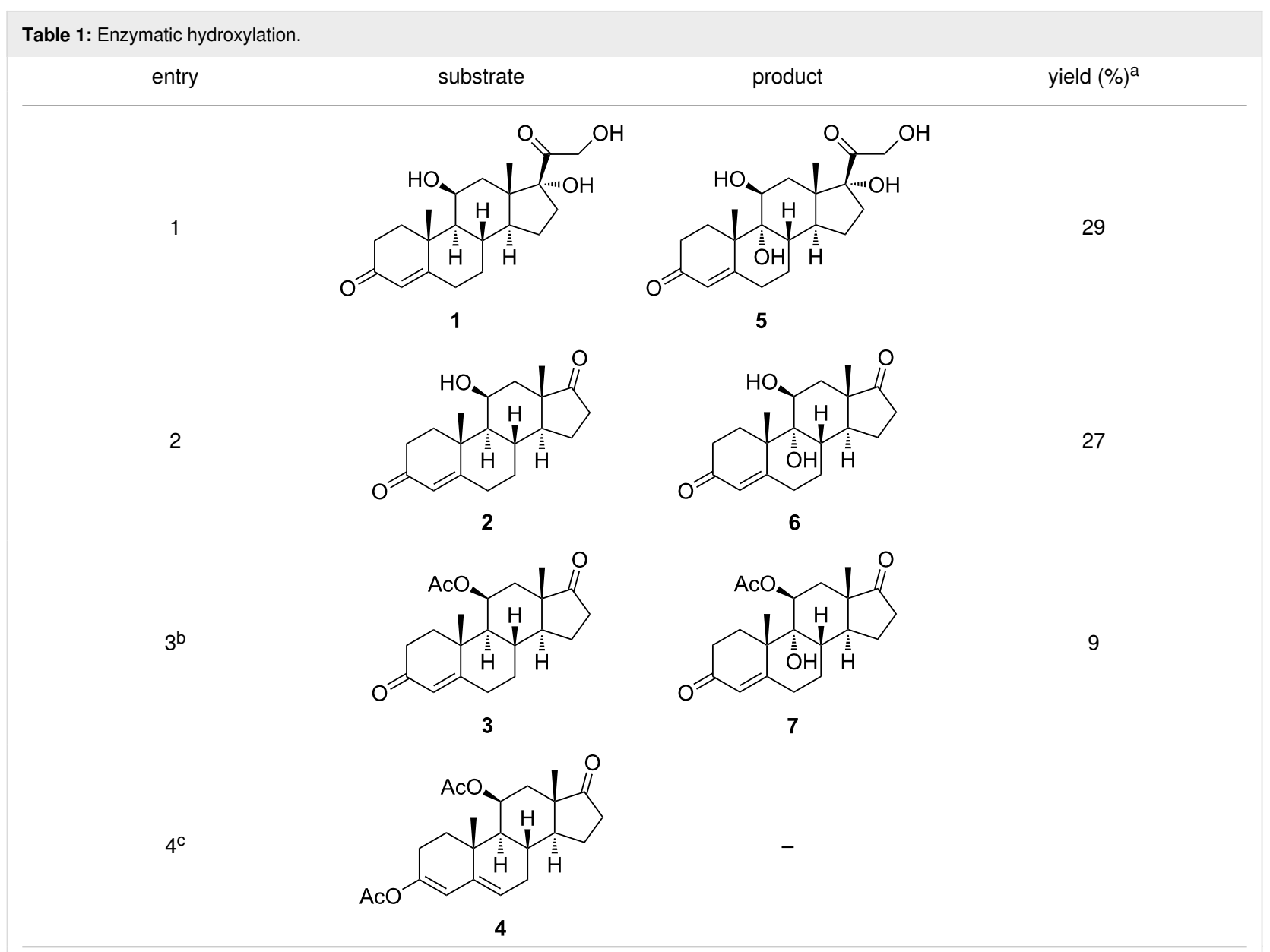

alsolated yield after column chromatography. ${ }^{\mathrm{b}} 23 \%$ of starting material was recovered. ${ }^{\mathrm{C}}$ No products were formed, only starting substrate was detected.

pound 8. However, using $\mathrm{NaOCl} \cdot 5 \mathrm{H}_{2} \mathrm{O}$ as an oxidant [31], diols 5 and $\mathbf{6}$ were effectively converted to the corresponding 9,11 secosterols 8 and $\mathbf{9}$ within one hour at $0{ }^{\circ} \mathrm{C}$ (Scheme 3).

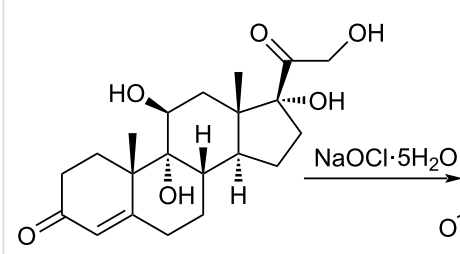

5<smiles>C[C@]12C[C@@H](O)[C@H]3[C@@H](CCC4=CC(=O)CC[C@@]43C)[C@]1(C)CCC2=O</smiles>

6

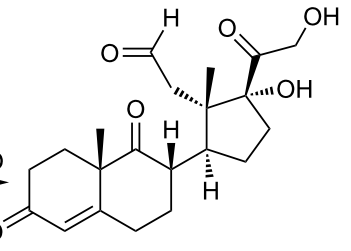

8<smiles>C[C@]12CC(=O)C=C1CC[C@H]([C@H]1CCC(=O)[C@@]1(C)CC=O)C2=O</smiles>

9
Scheme 3: Oxidation of diols 5 and 6 with $\mathrm{NaOCl} \cdot 5 \mathrm{H}_{2} \mathrm{O}$.
Compound $\mathbf{8}$ was isolated as 2:1 mixture together with starting diol 5 and purified further by preparative TLC. Compound 9 was isolated as a single product in $87 \%$ yield.

\section{Conclusion}

We have presented the results of the synthesis of the 9,11secosteroid carbon skeleton by using the designed whole-cell biotransformation of natural steroids with a genetically engineered biocatalyst. The enzymatic oxidation of cortisol derivatives is completely stereo- and regioselective, affording only $9 \alpha$-hydroxylated diol. The following oxidative cleavage of the $\mathrm{C}-\mathrm{C}$ bond with a mild oxidant leads to the steroid with an appropriately broken steroid skeleton. The method provides the target compound in only two steps, without any manipulations involving protecting groups. The present method features mild reaction conditions, and the protocol tolerates several functional groups. It is an environmentally benign approach, totally excluding the use of highly toxic oxidants. Our synthetic scheme provides a direct entry to structurally diverse 9,11-secosterols, enabling also studies of their biological properties. 
Further research to broaden the scope of the presented synthetic scheme is ongoing.

\section{Experimental \\ General data}

Full assignment of ${ }^{1} \mathrm{H}$ and ${ }^{13} \mathrm{C}$ chemical shifts were based on the 1D and 2D FT NMR spectra, measured with a Bruker Avance III $400 \mathrm{MHz}$ or a Bruker Avance III $800 \mathrm{MHz}$ instrument. Residual solvent signals were used $\left(\mathrm{CDCl}_{3}: \delta=7.26\right.$ for ${ }^{1} \mathrm{H}$ NMR, $\delta=77.2$ for ${ }^{13} \mathrm{C} \mathrm{NMR}$ or $\mathrm{CD}_{3} \mathrm{OD}: \delta=3.31$ for ${ }^{1} \mathrm{H}$ NMR, $\delta=49.0$ for ${ }^{13} \mathrm{C}$ NMR) as internal standards. Optical rotations were obtained by using an Anton Paar GWB Polarimeter MCP500. High-resolution mass spectra were recorded with an Agilent Technologies 6540 UHD AccurateMass QTOF LC/MS spectrometer by using AJ-ESI as an ionization method.

\section{Construction of biocatalyst}

Plasmid cloning and amplification were performed in E. coli DH5 strain. E. coli strain BL21 (DE3) was used for biocatalysis experiments. Lysogeny broth (LB) medium was used for all cell-growth incubations. For the selection of plasmids, $100 \mu \mathrm{g} / \mathrm{mL}$ ampicillin was used.

Plasmid pAJ30 for heterologous expression of $k s h A 5$ and $k s h B$ was constructed using the CPEC method [32]. $k s h A 5$ and $k s h B$ gene sequences from $R$. rhodochrous were codon-optimized for high-level expression in $E$. coli using the IDT codon optimization tool (to eliminate rare codons). Synthetic DNA was ordered from Twist Bioscience and inserted into pET21a backbone as one operon (see Supporting Information File 2) under the control of an IPTG-inducible tac promoter. The obtained plasmid was verified by DNA sequencing. To obtain the biocatalyst strain, the plasmid pAJ30 was transformed into chemically competent $E$. coli BL21 (DE3) cells.

\section{Enzymatic hydroxylation}

$3 \mathrm{~mL}$ precultures of BL21(DE3) transformed with pAJ30 plasmid (biocatalyst) or without plasmid (negative control) were grown overnight at $37{ }^{\circ} \mathrm{C}$. The next morning, $200 \mathrm{~mL}$ of LB medium in a $2 \mathrm{~L}$ baffled flask was inoculated with $1 \mathrm{~mL}$ of a preculture. The cultures were grown until $\mathrm{OD}_{600}=0.1$ at $37{ }^{\circ} \mathrm{C}$ with continuous shaking at $220 \mathrm{rpm}$, and then the expression was induced by adding $1 \mathrm{mM}$ IPTG and a substrate (compound 1-4, respectively) at a final concentration of $225 \mu \mathrm{g} / \mathrm{mL}$, $175 \mu \mathrm{g} / \mathrm{mL}, 190 \mu \mathrm{g} / \mathrm{mL}$ or $122 \mu \mathrm{g} / \mathrm{mL}$, respectively. The biocatalysis was carried out for 20 hours at $30{ }^{\circ} \mathrm{C}$ with continuous shaking at $220 \mathrm{rpm}$. The next morning, the cells were harvested by centrifugation at $4,000 \mathrm{~g}$, and cell pellet and culture supernatant were stored at a temperature of $-20{ }^{\circ} \mathrm{C}$ until further analysis.

\section{Synthesis of substrates}

\section{$11 \beta$-Hydroxyandrost-4-ene-3,17-dione (2)}

To a stirred solution of cortisol $(\mathbf{1}, 1.2 \mathrm{~g}, 3.36 \mathrm{mmol})$ in a 1:1 mixture of EtOH and $\mathrm{CH}_{2} \mathrm{Cl}_{2}(23 \mathrm{~mL}), \mathrm{NaBH}_{4}(51.2 \mathrm{mg}$, $1.35 \mathrm{mmol}$ ) was added in one portion at room temperature. After $2 \mathrm{~h}$, acetone $(5.8 \mathrm{~mL})$ was added, followed by water $(5.8 \mathrm{~mL})$ and $\mathrm{NaIO}_{4}(1.8 \mathrm{~g}, 8.41 \mathrm{mmol})$. The solution was stirred overnight at room temperature. Water $(115 \mathrm{~mL})$ was added, and the reaction mixture was extracted with $\mathrm{CHCl}_{3}$ $(3 \times 50 \mathrm{~mL})$. The combined organic layers were dried over sodium sulfate and filtered. After evaporation of the solvent, ketone $2(1.01 \mathrm{~g}, 99 \%)$ was isolated as white amorphous solid. $[\alpha]_{\mathrm{D}}{ }^{20}+177.4\left(c 0.46, \mathrm{CHCl}_{3}\right) ;{ }^{1} \mathrm{H} \mathrm{NMR}\left(\mathrm{CDCl}_{3}, 400 \mathrm{MHz}\right)$ $\delta 5.69(\mathrm{~d}, J=1.3 \mathrm{~Hz}, 1 \mathrm{H}), 4.45(\mathrm{q}, J=3.0 \mathrm{~Hz}, 1 \mathrm{H}), 2.58-1.97$ $(\mathrm{m}, 10 \mathrm{H}), 1.95(\mathrm{dd}, J=14.4,2.7 \mathrm{~Hz}, 1 \mathrm{H}), 1.85(\mathrm{td}, J=13.5$, $4.6 \mathrm{~Hz}, 1 \mathrm{H}), 1.73-1.58(\mathrm{~m}, 1 \mathrm{H}), 1.52-1.47(\mathrm{~m}, 1 \mathrm{H}), 1.46(\mathrm{~s}$, $3 \mathrm{H}), 1.34-1.18(\mathrm{~m}, 2 \mathrm{H}), 1.16(\mathrm{~s}, 3 \mathrm{H}), 1.14-1.06(\mathrm{~m}, 1 \mathrm{H}), 1.00$ $(\mathrm{dd}, J=11.1,3.3 \mathrm{~Hz}, 1 \mathrm{H}) ;{ }^{13} \mathrm{C} \mathrm{NMR}\left(\mathrm{CDCl}_{3}, 101 \mathrm{MHz}\right)$ ठ $219.19,199.48,171.63,122.70,68.07,56.80,52.49,46.84$, 41.13, 39.43, 35.41, 35.15, 33.93, 31.95, 31.62, 31.09, 21.80, 21.20, 15.99; HRMS $(\mathrm{m} / \mathrm{z}):[\mathrm{M}+\mathrm{H}]^{+}$calcd, 303.1955; found, 303.1961 .

\section{$11 \beta$-Acetoxyandrost-4-ene-3,17-dione (3)}

Starting steroid 2 (202 mg, $0.67 \mathrm{mmol}, 1$ equiv) was dissolved in dry dichloromethane $(9.8 \mathrm{~mL})$, and after that 4-(dimethylamino)pyridine ( $8.2 \mathrm{mg}, 0.067 \mathrm{mmol}, 0.1$ equiv), triethylamine (373 $\mu \mathrm{L}, 2.67 \mathrm{mmol}, 4$ equiv) and acetic anhydride $(316 \mu \mathrm{L}$, $3.34 \mathrm{mmol}, 5$ equiv) were added. The mixture was stirred under argon atmosphere overnight at room temperature. Saturated aqueous $\mathrm{NH}_{4} \mathrm{Cl}(4.11 \mathrm{~mL})$ was added, and the reaction mixture was extracted with $\mathrm{CH}_{2} \mathrm{Cl}_{2}(4 \times 6 \mathrm{~mL})$. The combined organic layers were dried over sodium sulfate, filtered and then concentrated in vacuo. The residue was chromatographed on silica gel with gradient $10 \%$ to $40 \%$ acetone in petroleum ether to give acetate $3(213.2 \mathrm{mg}, 93 \%)$ as pale yellow oil. $[\alpha]_{\mathrm{D}}{ }^{20}+180.0\left(c 0.58, \mathrm{CHCl}_{3}\right) ;{ }^{1} \mathrm{H} \mathrm{NMR}\left(\mathrm{CDCl}_{3}\right.$, $400 \mathrm{MHz}) \delta 5.68$ (d, $J=1.4 \mathrm{~Hz}, 1 \mathrm{H}), 5.47$ (q, $J=3.1 \mathrm{~Hz}, 1 \mathrm{H})$, 2.57-2.21 (m, 6H), 2.20-2.05 (m, 4H), 2.04 (s, 3H), 1.99 $(\mathrm{m}, 1 \mathrm{H}), 1.85-1.74(\mathrm{~m}, 1 \mathrm{H}), 1.69-1.60(\mathrm{~m}, 1 \mathrm{H}), 1.42(\mathrm{dd}$, $J=14.9,3.3 \mathrm{~Hz}, 1 \mathrm{H}), 1.28(\mathrm{~s}, 3 \mathrm{H}), 1.21-1.10(\mathrm{~m}, 3 \mathrm{H}), 1.03$ $(\mathrm{s}, 3 \mathrm{H}) ;{ }^{13} \mathrm{C} \mathrm{NMR}\left(\mathrm{CDCl}_{3}, 101 \mathrm{MHz}\right) \delta 217.94,198.85$, 170.13, 169.58, 123.08, 69.41, 55.60, 52.11, 46.48, 38.76, $36.99,35.48,35.27,33.71,31.82$, 31.65, 31.34, 21.90, 21.71, 20.87, 15.56; HRMS $(\mathrm{m} / \mathrm{z}):[\mathrm{M}+\mathrm{H}]^{+}$calcd, 345.2060; found, 345.2078 .

\section{3,11ß-Bis(acetyloxy)androsta-3,5-dien-17-one (4)}

The general procedure of Marwah et al. [28] was followed with modifications. A mixture of steroid $2(254 \mathrm{mg}, 0.84 \mathrm{mmol}$, 1 equiv), acetic anhydride ( $475 \mu \mathrm{L}, 5.03 \mathrm{mmol}, 6$ equiv) and 
p-toluenesulfonic acid monohydrate $(2.8 \mathrm{mg}, 0,008 \mathrm{mmol}$, 0,01 equiv) in a beaker was subjected to continuous mode of microwave irradiation $(800 \mathrm{~W})$ at high power setting in a domestic microwave oven for $6 \mathrm{~min}$. After this, the mixture was cooled to room temperature, and saturated aqueous $\mathrm{NaHCO}_{3}$ $(5 \mathrm{~mL})$ was added, after which this was mixed and extracted with EtOAc $(5 \mathrm{~mL})$. The organic layer was dried over magnesium sulfate, filtered and concentrated in vacuo. The residue was chromatographed on silica gel with gradient $7 \%$ to $30 \%$ acetone in petroleum ether to give monoacetate $3(151 \mathrm{mg}$, $52 \%)$ and diacetate $4(107 \mathrm{mg}, 33 \%)$. Diacetate 4: ${ }^{1} \mathrm{H}$ NMR $\left(\mathrm{CDCl}_{3}, 400 \mathrm{MHz}\right) \delta 5.66(\mathrm{~d}, J=2.1 \mathrm{~Hz}, 1 \mathrm{H}), 5.50(\mathrm{q}$, $J=3.2 \mathrm{~Hz}, 1 \mathrm{H}), 5.33(\mathrm{t}, J=3.8 \mathrm{~Hz}, 1 \mathrm{H}), 2.67-2.36(\mathrm{~m}, 4 \mathrm{H})$, $2.29(\mathrm{~m}, 1 \mathrm{H}), 2.12(\mathrm{~s}, 3 \mathrm{H}), 2.11-2.04(\mathrm{~m}, 4 \mathrm{H}), 2.03(\mathrm{~s}, 3 \mathrm{H})$, $2.01-1.96(\mathrm{~m}, 1 \mathrm{H}), 1.95-1.84(\mathrm{~m}, 1 \mathrm{H}), 1.75(\mathrm{dd}, J=12.7$, $4.2 \mathrm{~Hz}, 1 \mathrm{H}), 1.70-1.62(\mathrm{~m}, 1 \mathrm{H}), 1.51-1.12(\mathrm{~m}, 2 \mathrm{H}), 1.08(\mathrm{~s}$, $3 \mathrm{H}), 1.03(\mathrm{~s}, 3 \mathrm{H}) ;{ }^{13} \mathrm{C} \mathrm{NMR}\left(\mathrm{CDCl}_{3}, 101 \mathrm{MHz}\right) \delta 218.48$, $169.85,169.41,147.42,140.45,122.24,116.12,69.66,53.31$, 50.99, 46.72, 37.01, 35.38, 34.90, 33.49, 30.73, 28.37, 24.60, $21.96,21.79,21.54,21.21,15.50 ; \operatorname{HRMS}(\mathrm{m} / \mathrm{z}):[\mathrm{M}+\mathrm{H}]^{+}$ calcd, 387.2166; found, 387.2167.

\section{Isolation of 9-hydroxysteroids}

A frozen culture supernatant was melted at room temperature or in a warm water bath, then poured into the separation funnel, saturated by the addition of solid sodium chloride and extracted with EtOAc. The extract was concentrated in vacuo to give a solid residue that was chromatographed on silica gel. Elution with acetone/petroleum ether solvent system ( $30 \%$ to $50 \%$ for 5 and $\mathbf{6}, 10 \%$ to $30 \%$ for 7 ) afforded the product.

\section{9-Hydroxysteroids \\ $9 \alpha, 11 \beta, 17 \alpha, 21-$ Tetrahydroxypregn-4-ene- 3,20-dione (5)}

Compound 5 was further purified by column chromatography on silica gel with $10 \% \mathrm{MeOH} / \mathrm{CHCl}_{3} \cdot[\alpha]_{\mathrm{D}}{ }^{20}+119.2(c 0.66$, $\mathrm{MeOH}$ ); ${ }^{1} \mathrm{H}$ NMR (MeOD, $\left.400 \mathrm{MHz}\right) \delta 5.72$ (s, 1H), 4.64 (d, $J=19.2 \mathrm{~Hz}, 1 \mathrm{H}), 4.26(\mathrm{~d}, J=19.1 \mathrm{~Hz}, 1 \mathrm{H}), 4.05(\mathrm{t}, 1 \mathrm{H}), 2.73$ (ddd, $J=14.2,11.2,2.7 \mathrm{~Hz}, 1 \mathrm{H}), 2.67-2.54(\mathrm{~m}, 1 \mathrm{H}), 2.53-2.46$ $(\mathrm{m}, 2 \mathrm{H}), 2.43-2.22(\mathrm{~m}, 8 \mathrm{H}), 2.02-1.94(\mathrm{~m}, 1 \mathrm{H}), 1.70(\mathrm{dt}$, $J=10.9,5.6 \mathrm{~Hz}, 2 \mathrm{H}), 1.58(\mathrm{~s}, 3 \mathrm{H}), 1.49$ (ddd, $J=14.9,9.2$, $6.4 \mathrm{~Hz}, 1 \mathrm{H}), 1.42-1.36(\mathrm{~m}, 2 \mathrm{H}), 0.87(\mathrm{~s}, 3 \mathrm{H}) ;{ }^{13} \mathrm{C} \mathrm{NMR}$ $\left(\mathrm{CD}_{3} \mathrm{OD}, 201 \mathrm{MHz}\right) \delta 213.08,202.81,176.40,124.85,90.50$, 78.81, 73.87, 67.69, 48.27, 46.75, 46.25, 36.83, 35.36, 34.86, $34.75,32.33,29.11,26.84,24.54,22.49,17.60$; HRMS $(\mathrm{m} / \mathrm{z})$ : $[\mathrm{M}+\mathrm{H}]^{+}$calcd, 303.1955; found, 303.1961.

\section{9 $\alpha, 11 \beta$-Dihydroxyandrost-4-ene-3,17-dione (6)}

${ }^{1} \mathrm{H}$ NMR $\left(\mathrm{CD}_{3} \mathrm{OD}, 800 \mathrm{MHz}\right) \delta 5.74(\mathrm{ddd}, J=2.1,0.8,0.5 \mathrm{~Hz}$, $1 \mathrm{H}), 4.03(\mathrm{dd}, J=3.3,2.6 \mathrm{~Hz}, 1 \mathrm{H}), 2.64(\mathrm{dddd}, J=15.4,13.3$,
6.9, $2.1 \mathrm{~Hz}, 1 \mathrm{H}), 2.53(\mathrm{ddd}, J=12.5,11.2,4.7 \mathrm{~Hz}, 1 \mathrm{H}), 2.52$ (ddd, $J=16.1,14.4,5.3 \mathrm{~Hz}, 1 \mathrm{H}), 2.48(\mathrm{ddd}, 19.2,8.8,0.9 \mathrm{~Hz}$, $1 \mathrm{H}$ ), 2.45 (dddd, $J=14.4,13.0,4.3,0.5 \mathrm{~Hz}, 1 \mathrm{H}$ ), 2.34 (dddd, $J=16.1,4.3,3.1,0.8 \mathrm{~Hz}, 1 \mathrm{H}), 2.30$ (dddd, $J=15.4,5.6,1.5$, $0.5 \mathrm{~Hz}, 1 \mathrm{H}), 2.06(\mathrm{dt}, J=19.2,8.8,8.8 \mathrm{~Hz}, 1 \mathrm{H}), 1.99$ (ddd, $J=13.0,5.3,3.2 \mathrm{~Hz}, 1 \mathrm{H}), 1.91(\mathrm{~m}, 1 \mathrm{H}), 1.89(\mathrm{~m}, 1 \mathrm{H}), 1.82$ (ddddd, $J=13.3,6.9,4.7,1.5,0.5 \mathrm{~Hz}, 1 \mathrm{H}$ ), 1.73 (bdd, $J=14.0$, $3.3 \mathrm{~Hz}, 1 \mathrm{H}), 1.72$ (dd, $J=14.0,2.6 \mathrm{~Hz}, 1 \mathrm{H}), 1.68(\mathrm{~m}, 1 \mathrm{H}), 1.66$ (dddd, $J=13.3,13.3,12.5,5.6 \mathrm{~Hz}, 1 \mathrm{H}), 1.61(\mathrm{~d}, J=0.5 \mathrm{~Hz}$, $3 \mathrm{H}), 1.16(\mathrm{~s}, 3 \mathrm{H}) ;{ }^{13} \mathrm{C} \mathrm{NMR}\left(\mathrm{CD}_{3} \mathrm{OD}, 201 \mathrm{MHz}\right) \delta 222.73$, 202.58, 175.91, 124.93, 79.13, 73.30, 48.17, 46.78, 46.50, $37.32,36.34,34.80,34.76,32.08,29.01,25.55,22.46,22.35$, 15.89; HRMS $(\mathrm{m} / \mathrm{z}):[\mathrm{M}+\mathrm{H}]^{+}$calcd, 319.1904; found, 319.1866 .

\section{$9 \alpha$-Hydroxy-11ß-acetyloxyandrost-4-ene- \\ 3,17-dione (7)}

$[\alpha]_{\mathrm{D}}{ }^{20}+157.3\left(c 0.23, \mathrm{CHCl}_{3}\right) ;{ }^{1} \mathrm{H} \mathrm{NMR}(\mathrm{MeOD}, 400 \mathrm{MHz})$ $\delta 5.75(\mathrm{~d}, J=1.9 \mathrm{~Hz}, 1 \mathrm{H}), 5.10(\mathrm{t}, J=3.0 \mathrm{~Hz}, 1 \mathrm{H}), 2.60-2.41$ (m, 4H), 2.38-2.27 (m, 2H), $2.16(\mathrm{~d}, J=9.5 \mathrm{~Hz}, 4 \mathrm{H}), 2.07(\mathrm{~s}$, $3 \mathrm{H}), 2.05-1.91(\mathrm{~m}, 1 \mathrm{H}), 1.85$ (dddd, $J=13.4,6.8,4.8,1.7 \mathrm{~Hz}$, $1 \mathrm{H}), 1.78(\mathrm{~d}, J=3.0 \mathrm{~Hz}, 2 \mathrm{H}), 1.73-1.64(\mathrm{~m}, 1 \mathrm{H}), 1.62-1.52(\mathrm{~m}$, $1 \mathrm{H}), 1.49(\mathrm{~s}, 3 \mathrm{H}), 1.05(\mathrm{~s}, 3 \mathrm{H}) ;{ }^{13} \mathrm{C} \mathrm{NMR}(\mathrm{MeOD}, 101 \mathrm{MHz})$

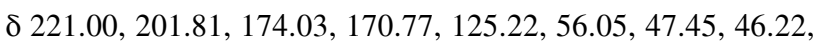
46.01, 36.17, 35.43, 34.63, 33.93, 32.02, 29.74, 29.53, 25.38, 22.82, 22.25, 21.63, 15.59; HRMS $(\mathrm{m} / \mathrm{z}):[\mathrm{M}+\mathrm{Na}]^{+}$calcd, 383.1829; found, 383.1825 .

\section{Chemical oxidation of 9,11-dihydroxysteroids}

The general procedure of Kirihara et al. [31] was followed. Sodium hypochlorite pentahydrate (3 equiv) was added to a stirred solution of diol (1 equiv) and tetrabutylammonium hydrogen sulfate $(0.1$ equiv) in dichloromethane $(8 \mathrm{~mL} / \mathrm{mmol}$ diol) and water $(2.7 \mathrm{~mL} / \mathrm{mmol}$ diol $)$ at $0{ }^{\circ} \mathrm{C}$. The resulting mixture was stirred for $1 \mathrm{~h}$ and monitored by TLC analysis (10\% $\mathrm{MeOH}$ in $\left.\mathrm{CHCl}_{3}\right)$. Water $(2.7 \mathrm{~mL} / \mathrm{mmol}$ diol $)$ was added, and the reaction mixture was extracted with $\mathrm{CH}_{2} \mathrm{Cl}_{2}$ $(2 \times 32 \mathrm{~mL} / \mathrm{mmol}$ diol $)$. The combined organic layers were dried over anhydrous sodium sulfate, filtered and then concentrated in vacuo.

\section{7 $\alpha, 21$-Dihydroxy-3,9,20-trioxo-9,11-seco-pregn-4- en-11-al (8)}

Compound $\mathbf{8}$ was obtained as a mixture with $\mathbf{5}$ in the ratio 2:1. Compound 8 was further purified by preparative TLC $(10 \%$ $\mathrm{MeOH}$ in $\mathrm{CHCl}_{3}$ ); ${ }^{1} \mathrm{H}$ NMR (MeOD, $\left.400 \mathrm{MHz}\right) \delta 9.60$ (s, $1 \mathrm{H}$, $\mathrm{H}-11), 5.81$ (d, $J=2.3 \mathrm{~Hz}, 1 \mathrm{H}, \mathrm{H}-4), 1.50$ (s, 3H, 19-Me), 0.83 (s, 3H, 18-Me); ${ }^{13} \mathrm{C} \mathrm{NMR}\left(\mathrm{CDCl}_{3}, 101 \mathrm{MHz}\right) \delta 221.31$ (C9), 211.52 (C20), 200.50 (C11), 198.19 (C3), 165.72 (C5), 125.90 (C4); HRMS $(\mathrm{m} / \mathrm{z}):[\mathrm{M}+\mathrm{H}]^{+}$calcd, 377.1959; found, 377.1944 . 


\section{3,9-Dioxo-9,11-secoandrost-4-en-11-al (9)}

Compound 9 was obtained as pure compound with a yield of $87 \% .[\alpha]_{\mathrm{D}}{ }^{20}+57.1\left(c \quad 0.42, \mathrm{CHCl}_{3}\right) ;{ }^{1} \mathrm{H}$ NMR $\left(\mathrm{CDCl}_{3}\right.$, $400 \mathrm{MHz}) \delta 9.69(\mathrm{~d}, J=0.8 \mathrm{~Hz}, 1 \mathrm{H}), 5.83(\mathrm{~d}, J=2.0 \mathrm{~Hz}, 1 \mathrm{H})$, $3.40-3.28(\mathrm{~m}, 1 \mathrm{H}), 3.00-2.73(\mathrm{~m}, 5 \mathrm{H}), 2.66-2.54(\mathrm{~m}, 2 \mathrm{H})$, $2.51-2.36(\mathrm{~m}, 2 \mathrm{H}), 2.30-2.16(\mathrm{~m}, 1 \mathrm{H}), 2.10-2.01(\mathrm{~m}, 1 \mathrm{H}), 1.95$ (ddd, $J=14.1,4.8,3.2 \mathrm{~Hz}, 1 \mathrm{H}), 1.74-1.53(\mathrm{~m}, 1 \mathrm{H}), 1.51$ (s, $3 \mathrm{H}), 1.49-1.37(\mathrm{~m}, 2 \mathrm{H}), 0.84(\mathrm{~s}, 3 \mathrm{H}) ;{ }^{13} \mathrm{C} \mathrm{NMR}\left(\mathrm{CDCl}_{3}\right.$, $101 \mathrm{MHz}) \delta 221.30,211.50,200.48,198.17,165.72,125.87$, 51.55, 51.30, 48.56, 47.37, 39.82, 36.20, 33.60, 32.45, 29.62, 28.98, 23.72, 22.99, 18.49; HRMS $(\mathrm{m} / \mathrm{z}):[\mathrm{M}+\mathrm{H}]^{+}$calcd, 317.1747; found, 317.1755 .

\section{Supporting Information}

\section{Supporting Information File 1}

General material and methods for the construction of the

biocatalyst as well as NMR spectra of synthesized

compounds.

[https://www.beilstein-journals.org/bjoc/content/

supplementary/1860-5397-17-52-S1.pdf]

\section{Supporting Information File 2}

DNA sequence.

[https://www.beilstein-journals.org/bjoc/content/ supplementary/1860-5397-17-52-S2.gb]

\section{Funding}

The authors thank the Estonian Ministry of Education and Research (Grant Nos. PRG657 and PRG1031) and the Centre of Excellence in Molecular Cell Engineering (2014-2020.4.01.150013) for financial support.

\section{ORCID ${ }^{\circledR}$ iDs}

Marje Kasari - https://orcid.org/0000-0002-2177-3753 Villu Kasari - https://orcid.org/0000-0002-2970-2001 Ivar Järving - https://orcid.org/0000-0001-6047-4759 Arvi Jõers - https://orcid.org/0000-0003-2083-3977 Tõnis Kanger - https://orcid.org/0000-0001-5339-9682

\section{References}

1. Li, J.; Amatuni, A.; Renata, H. Curr. Opin. Chem. Biol. 2020, 55, 111-118. doi:10.1016/j.cbpa.2020.01.005

2. Fryszkowska, A.; Peterson, J.; Davies, N. L.; Dewar, C.; Evans, G.; Bycroft, M.; Triggs, N.; Fleming, T.; Gorantla, S. S. C.; Hoge, G.; Quirmbach, M.; Timmanna, U.; Poreddy, S. R.; Reddy, D. N. K.; Dahanukar, V.; Holt-Tiffin, K. E. Org. Process Res. Dev. 2016, 20 , 1520-1528. doi:10.1021/acs.oprd.6b00215
3. Carvalho, J. F. S.; Silva, M. M. C.; Moreira, J. N.; Simões, S.; Melo, M. L. S. J. Med. Chem. 2009, 52, 4007-4019. doi:10.1021/jm9003973

4. Contente, M. L.; Molinari, F.; Serra, I.; Pinto, A.; Romano, D. Eur. J. Org. Chem. 2016, 1260-1263. doi:10.1002/ejoc.201501557

5. Noack, F.; Heinze, R. C.; Heretsch, P. Synthesis 2019, 51, 2039-2057. doi:10.1055/s-0037-1611576

6. Duecker, F. L.; Reuß, F.; Heretsch, P. Org. Biomol. Chem. 2019, 17, 1624-1633. doi:10.1039/c8ob02325e

7. Enwall, E. L.; van der Helm, D.; Hsu, I. N.; Pattabhiraman, T.; Schmitz, F. J.; Spraggins, R. L.; Weinheimer, A. J. J. Chem. Soc., Chem. Commun. 1972, 215-216. doi:10.1039/c39720000215

8. Koljak, R.; Pehk, T.; Järving, I.; Liiv, M.; Lopp, A.; Varvas, K.; Vahemets, A.; Lille, Ü.; Samel, N. Tetrahedron Lett. 1993, 34, 1985-1986. doi:10.1016/s0040-4039(00)91981-6

9. Lopp, A.; Pihlak, A.; Paves, H.; Samuel, K.; Koljak, R.; Samel, N. Steroids 1994, 59, 274-281. doi:10.1016/0039-128x(94)90113-9

10. Koljak, R.; Lopp, A.; Pehk, T.; Varvas, K.; Müürisepp, A.-M.; Järving, I.; Samel, N. Tetrahedron 1998, 54, 179-186. doi:10.1016/s0040-4020(97)10268-x

11. Huang, C.-Y.; Su, J.-H.; Duh, C.-Y.; Chen, B.-W.; Wen, Z.-H.; Kuo, Y.-H.; Sheu, J.-H. Bioorg. Med. Chem. Lett. 2012, 22, 4373-4376. doi:10.1016/j.bmcl.2012.05.002

12. Chang, Y.-C.; Hwang, T.-L.; Kuo, L.-M.; Sung, P.-J. Mar. Drugs 2017, 15, 11.

13. He, Y.-Q.; Lee Caplan, S.; Scesa, P.; West, L. M. Steroids 2017, 125, 47-53. doi:10.1016/j.steroids.2017.06.008

14. Chang, Y.-C.; Lai, K.-H.; Kumar, S.; Chen, P.-J.; Wu, Y.-H.; Lai, C.-L.; Hsieh, H.-L.; Sung, P.-J.; Hwang, T.-L. Mar. Drugs 2020, 18, 271.

15. Sica, D.; Musumeci, D. Steroids 2004, 69, 743-756. doi:10.1016/j.steroids.2004.09.001

16. Adinolfi, R.; Migliuolo, A.; Piccialli, V.; Sica, D. J. Nat. Prod. 1994, 57, 1220-1226. doi:10.1021/np50111a005

17. Jäälaid, R.; Järving, I.; Pehk, T.; Lille, Ü. Proc. Est. Acad. Sci., Chem. 1998, 47, 39-43.

18. Kuhl, A.; Kreiser, W. Tetrahedron Lett. 1998, 39, 1145-1148. doi:10.1016/s0040-4039(97)10875-9

19. Jäälaid, R.; Järving, I.; Pehk, T.; Parve, O.; Lille, Ü. Nat. Prod. Lett. 2001, 15, 221-228. doi:10.1080/10575630108041285

20. Kongkathip, B.; Hasakunpaisarn, A.; Boonananwong, S.; Kongkathip, N. Steroids 2010, 75, 834-847. doi:10.1016/j.steroids.2010.05.003

21. Salvador, J. A. R.; Silvestre, S. M.; Moreira, V. M. Curr. Org. Chem. 2012, 16, 1243-1276. doi:10.2174/138527212800564204

22. Warnke, M.; Jung, T.; Dermer, J.; Hipp, K.; Jehmlich, N.; von Bergen, M.; Ferlaino, S.; Fries, A.; Müller, M.; Boll, M. Angew. Chem., Int. Ed. 2016, 55, 1881-1884. doi:10.1002/anie.201510331

23. Ferrandi, E. E.; Bertuletti, S.; Monti, D.; Riva, S. Eur. J. Org. Chem. 2020, 4463-4473. doi:10.1002/ejoc.202000192

24. Li, A.; Acevedo-Rocha, C. G.; D’Amore, L.; Chen, J.; Peng, Y.; Garcia-Borràs, M.; Gao, C.; Zhu, J.; Rickerby, H.; Osuna, S.; Zhou, J.; Reetz, M. T. Angew. Chem., Int. Ed. 2020, 59, 12499-12505. doi:10.1002/anie.202003139

25. Acevedo-Rocha, C. G.; Gamble, C. G.; Lonsdale, R.; Li, A.; Nett, N.; Hoebenreich, S.; Lingnau, J. B.; Wirtz, C.; Fares, C.; Hinrichs, H.; Deege, A.; Mulholland, A. J.; Nov, Y.; Leys, D.; McLean, K. J.; Munro, A. W.; Reetz, M. T. ACS Catal. 2018, 8, 3395-3410. doi:10.1021/acscatal.8b00389 
26. Kerr, R. G.; Rodriguez, L. C.; Keliman, J. Tetrahedron Lett. 1996, 37 , 8301-8304. doi:10.1016/0040-4039(96)01942-9

27. Wüst, F.; Carlson, K. E.; Katzenellenbogen, J. A. Steroids 2003, 68 177-191. doi:10.1016/s0039-128x(02)00171-x

28. Marwah, P.; Marwah, A.; Lardy, H. A. Tetrahedron 2003, 59, 2273-2287. doi:10.1016/s0040-4020(03)00207-2

29. Petrusma, M.; Dijkhuizen, L.; van der Geize, R. Appl. Environ. Microbiol. 2009, 75, 5300-5307. doi:10.1128/aem.00066-09

30. Petrusma, M.; Hessels, G.; Dijkhuizen, L.; van der Geize, R. J. Bacteriol. 2011, 193, 3931-3940. doi:10.1128/jb.00274-11

31. Kirihara, M.; Osugi, R.; Saito, K.; Adachi, K.; Yamazaki, K.; Matsushima, R.; Kimura, Y. J. Org. Chem. 2019, 84, 8330-8336. doi:10.1021/acs.joc.9b01132

32. Quan, J.; Tian, J. Nat. Protoc. 2011, 6, 242-251. doi:10.1038/nprot.2010.181

\section{License and Terms}

This is an Open Access article under the terms of the Creative Commons Attribution License (https://creativecommons.org/licenses/by/4.0). Please note that the reuse, redistribution and reproduction in particular requires that the author(s) and source are credited and that individual graphics may be subject to special legal provisions.

The license is subject to the Beilstein Journal of Organic Chemistry terms and conditions: (https://www.beilstein-journals.org/bjoc/terms)

The definitive version of this article is the electronic one which can be found at: https://doi.org/10.3762/bjoc.17.52 